\title{
Research on Viewing the Modern Art Process of Contemporary China from Greenberg and Benjamin Theory
}

\author{
Shasha Wang ${ }^{1}$, Mingming Song ${ }^{2}$ \\ ${ }^{1}$ Xi'an University of Architecture and Technology Huaqing College, Xi'an, China, 710043 \\ ${ }^{2}$ Xi'an University of Technology, Xi'an, China, 710043
}

Keywords: the process of modern art; the founder of Western theory; the spirit of modern Chinese art

\begin{abstract}
Greenberg and Benjamin are two very important theorists in the history of Western art, respectively influencing the process of Western modern art and postmodern art. Many western artists were influenced by their theories and practiced a variety of modern art chapters. Contemporary Chinese art is advancing into the modern art process as a whole. However, it is not a repetition of the development of Western art. It is also different from the progressive development of Western art, but it integrates unique status quo of China and its artistic development context. This paper analyzes the theories of Western modern art and postmodern art, Greenberg and Benjamin's theories, and clarifies the origin of modern art in order to explore Chinese own modern art spirit in the contemporary Chinese modern art.
\end{abstract}

\section{Greenberg and "Avant-garde and Vulgarity"}

In 1938, Greenberg wrote the famous "Avant-garde and Vulgarity." Modern artists represented by Picasso, Kandinsky, Matisse, etc. represented Greenberg's "Avant-garde" art. Used to counter popular and commercial literary arts such as popular songs, Hollywood movies, magazine covers, illustrations, advertisements, cartoons, and tap dances produced in the middle of the 19th century. These widely popular cultural arts are called by Greenberg." The origin of vulgar culture stems from the influence of the capitalist industrial revolution. With the development of the industrial revolution, a large number of peasants migrated to cities to become proletarians. These peasants and small property owners learned culture for economic interests, but their level of control was limited after all and could not be compared with cultural cultivation under the conscious awareness of the society. They are faced with the loss of interest in folk culture with the background of the countryside, and at the same time they are faced with the troubles of adapting to the life of the city. This requires a new culture that can meet the demands of those with low cultural levels. "In order to meet market demands, a new kind of commodity was invented, a synthetic culture, a vulgar culture for those who have no sense of true cultural value, and they are only eager for the transformation that only a certain culture can provide. "The appearance of vulgar culture can satisfy the general cultural needs of these urbanized citizens in Western Europe and North America, and its low consumer prices and wide spread channels are therefore well received by the general public [1].

Greenberg opposed such a vulgar culture. Similarly, "avant-garde" also refers to having an anti-academic attitude against the established artistic language, which promotes the development of modern art. The birth of modern art is based on the rebellion of traditional art. In this article, for example, he supposes that a Soviet peasant came before two pictures, one was Picasso's painting, and the other was Repin's work representing the academics. When the peasants saw Picasso's works, he saw lines, color blocks, and strangely shaped people on the screen. This picture brought him some new sensory stimulation. In addition, he couldn't find anything else to read. Although Picasso's paintings express many of the primitive powers of human life related to the farming community, and this power has a close connection with the farmers themselves, it all feels to him because of the concealment of the screen message and the limitations of artistic cultivation. However, when he saw Repin's works, the very realistic skills and vivid theme of the painting made 
him immediately have a "reading" pleasure, and he found his value in the painting. The reality depicted by Repin is a beautified reality that is easily accepted and understood by the general public. As a result, the public tends to favor such academic works.

However, Greenberg criticized this lack of deep-thinking academic work, that it is a vulgar culture. From the comparison with Picasso's works, he pointed out that the reason for Picasso's painting became the result of the works of Repin. "The art that Repin pre-digested for the audience saved them energy, provided them with a shortcut to aesthetic pleasure, and bypassed the difficulties that real art must face." From the perspective of the influence on modern art, this view of Greenberg is a rebellion against the established artistic tradition. He has clearly denied the works that have been regarded as classics in order to open a new era of modern art.

The emergence of vulgar culture has led to the decline of traditional culture, and people are paying more attention to more simple, low-cost, easy-to-get cultural cultures such as movies and pop music that are easy to acquire. However, he saw the profound artistic value of the avant-garde culture and its contribution to the human spiritual civilization. Greenberg's banner clearly opposed the vulgar culture [2].

This criticism of Greenberg has been progressive. First of all, he took the works in the traditional sense as classics and pulled down the altar. At the same time, he considered market-oriented pop art as a vulgar culture with extremely low artistic content. A large number of artists were influenced by him and engaged in modern art. Modern art has therefore been able to develop on the basis of anti-traditionalism. "Avant-garde and Vulgar" was written in 1939. When the author was 29 years old, Greenberg became famous and influenced the development of modern art from the 1940s to the 1960s. It has become an important part of the history of modern art. Critics have a great influence. Another article by Greenberg, "Modernist Painting," expresses the idea of separating painting from life, and believes that modern artists should pay attention to the painting itself, such as the form and language of painting, rather than focusing on things other than life and painting. This has also led to the modern art history is almost a change of form and style, the artist tried his best to create new forms of art, form the top priority of modern art. This phenomenon was changed in the late 1960s.

\section{Benjamin and " The Work of Art in the Age of its Technical Reproducibility"}

Benjamin and Greenberg wrote two equally important articles at the same time, but they affected different periods. Greenberg and his "Avant-garde and Vulgarity" had a major influence on modern art, Benjamin and his writings " The Work of Art in the Age of its Technical Reproducibility" influenced the process of post-modern art. After Greenberg defined modern art as chasing the work itself, art was separated from life. After 1968, the artist was more influenced by Benjamin to engage in post-modern art that was contrary to Greenberg's advocacy for the modern art of elite art. Postmodern art more advocates the combination of art and human life. This article expresses a different point of view than Greenberg.

An important concept is often seen in the "artwork of the era of mechanical reproduction", which is "aura". What is aura? Benjamin exemplifies in the text that people in the Greek era wanted to worship God. Just walk through the Temple of the Lamb and see the sculptures in it. This will satisfy the desire for contact with God. This sculpture with uniqueness has " aura " because it is the only statue that can feel God's existence. But now it is different. The emergence of the era of mechanical reproduction has allowed art to be reproduced in large numbers. The popularity of photographic technology has made it possible for people to see that God can also achieve this through photograph, or by replicating sculptures in temples. However, the halo disappeared between the original and the replica. [3]

Aura refers to the uniqueness of works of art. At the same time, it encompasses both the time and space of the work, that is, immediate and immediateness. Another example is Van Gogh's work. People can use the detection technology to test the oil on the work to determine whether it is original. When the test results show that it is an original work, people can see the value of the original work. A large number of copies of works appear, people can buy a lot of cheap imitations, but the imitation of these " aura " also disappeared. 
Benjamin encouraged such works of art to be built in the era of mechanical reproduction under the premise of the disappearance of the halo. This typical representative is film and photography. The emergence of the film has made it easy for the public to accept it and it has been widely disseminated. People can enjoy a movie with very little money. Benjamin thinks this is advancement in art. Art no longer belongs to only a few privileged people, but it also integrates into the lives of the general public. His view shocked Greenberg's view that art should focus on the art of elite modern art, thus promoting the development of post-modern art. Pop Art represented by Andy Warhol is the practice of Benjamin's "The Work of Art in the Age of its Technical Reproducibility”. Although he never explained the works himself, his works have a wide range of commercial properties and pop art. Communication is exactly the same as Benjamin's. They are all advocates for the integration of art with the lives of the general public.

\section{The Contemporary Chinese Modern Art Process Needs to Explore Chinese Own Modern Art Spirit}

Greenberg and Benjamin respectively represent the concept of art practice in different phases of western modern art and postmodern art. Through the representative articles of these two theorists, they can explore the development process of the entire western modern art history. It is not difficult to see that from the pursuit of the mutated form of modernism to the search for meaning of postmodern art, artists in addition to seeking new "style" also give new ideas to the art. Therefore, there is a sequence between modern and postmodern, and postmodern is a denial of modernity. Different from the development of modern art and postmodern art in Western countries, contemporary China has entered the period of transition and great development of modern society since its reform and opening up, which is different from the modern history of the West. Similarly, the development of Chinese modern art is also different from that of the West. The progressive development of the West has experienced self-realism, Impressionism, post-impressionism, Art Nouveau, Fauvism, German Expressionism, Cubism, Dada, and surrealism. The school of art, movement, abstract expressionism, pop art, conceptual art, etc., formed a complete modern art process from the time width and richness of art types. In China, since the reform and opening up, the influx of Western culture has brought great impact on artists. Therefore, the art exhibition represented by the New Wave Movement and the Star School has become the beginning of modern Chinese art. Since then, modern art has spread in China, and artists have not consistently practiced the concept of western modern art. However, at this time, the methods and channels for accepting modern art are still relatively limited, and the choice of the political system for the value of the arts, and the mainstream art system is still dominated by the introduction of the Soviet art system. Therefore, in the education of the Chinese Academy of Fine Arts, it is widely prevalent. This is not unanimous with Greenberg's critical and vulgar culture. Academic colleges are the main fortress for the cultivation of artists. Therefore, the arts from the Academy of Fine Arts to the society, have a color of vulgar culture. In contrast, the development of modern art is more active in the civil society at this time. And it has scattered and unsystematic features.

In the 21st century, with the increase of transnational exchanges and the advent of the information age, postmodern art has been widely introduced to China. Fine art colleges have also expanded the courses of experimental art and contemporary art linking western postmodern art, but The Soviet teaching system still coexists. This kind of introduction to postmodern art is also optional, or it can be taught sporadically by one or two lessons in the form of lectures given by foreign professors in China, which does not make major changes to the basic teaching system. Some international academic forums and international exhibitions are also blossoming all over the country. China seems to be an experimental field for both modern and contemporary art at home and abroad. However, most artists or scholars coming to China often do not see the content that truly contributes to the world. The current art is disappointed. Why are we full of enthusiasm but we cannot get the respect we deserve? Mostly because of the short period of 30 years of reform and opening up, the development of Chinese art has experienced the process of learning from the West. We are still learning and exploring the stage. We have not yet formed our own, different from 
Western modern art discourse and form. Looking at the development of Western modern art, there are theorists and critics such as Greenberger and Benjamin in each period, leading everyone toward a direction that art should develop in this way, and thus form in this historical category. Schools, sports, and various forms of diversification can be called the phenomenon of modern art.

In reviewing the 30 years of modern Chinese art, there are many artists who have learned, introduced and tried and even imitated various modern schools in the West. It also has the heritage and innovation of traditional art. We often say that we must innovate, but there are few innovations that can be found in the arts. Our modern art has not yet formed the normal phenomenon that can be called "ism", "sports" and "genre" in the modern book, and has not yet formed a new brand-new understanding and practice of art that can contribute to the world. This may require a long way to go, but in this process, we should introspect ourselves that the process of learning the West should not merely copy and imitate the surface-rization of Western art, or that many experiments that have been done in the West As the spirit of Chinese modern art, art must know that the occurrence and development of each school of art must be related to its specific social and cultural background. We copy the imitation without thinking, and we do not fundamentally analyze and deeply understand the spirit of art. In essence, it is not helpful to form your own unique art.

The theories of Greenberg and Benjamin provide a good reference for the development of Chinese art. They clearly present the basic values and concepts of Western modern art history. However, with the globalization today, cultural collisions and exchanges have become more prominent. Today, with the vigorous development of culture and art, people seem to be accustomed to investing in advanced Western civilization and neglecting what they can do. The practice of contemporary China in the field of art should focus more on its own cultural and social background. Based on learning and drawing on the achievements of the West, it can dig out its own art that is different from the West, and strive to contribute to the new world. The arts with Chinese contemporary spirit, with real artistic value and profound connotation, contribute to the development of world arts and promote the common development of human spiritual civilization.

\section{References}

[1] H.H. Arnason. Histoty of Modern Art. Laurence King Publishing Ltd, London.2004.112

[2] Clement Greenberg. Avant-Garde and Kitsch. Table of Contents.63

[3] Walter Benjamin. The Work of Art in the Age of its Technical Reproducibility. Art and Its Significance. State University of New York Press.48 